\title{
Prospects for Post COVID-19 Era Optimisation of the Forest Products Industry in Nigeria
}

\author{
Ogunwusi A. A. Ibrahim H. D. \\ Raw Materials Research and Development Council, Abuja
}

\begin{abstract}
COVID-19 pandemic has taught nations a number of lessons.. The lockdown by nations to slow the spread of the disease created a demand and supply shocks that led to drop in international trade and investment flows of $30 \%$ to $40 \%$ respectively. Nigeria is not immune from this development. The country also depends on importation of secondary raw materials for its industries. As a result of acute deforestation, the economic wood species in Nigeria have reduced significantly forcing the forest industries to rely on importation of raw materials such as Plywood, Medium and High Density Fibreboards, ${ }^{0}$ OSR boards and a host of others as most of the particleboard and plymills have closed operation as a result of unavailability of prime wood species. The near absolute dependence on these raw materials led to disruption in the operation of the forest industries as a result of the lockdown in international trade occasioned by the CODID-19 pandemic. Production of most items in the sector has reduced significantly. For instance the sawmills operated at $28 \%$ of its installed capacity while the plymills and particleboard mills operated at below $12 \%$ and capacity utilisation respectively. This development necessitates the need for adequate plans to be made for the post COVID-19 era optimisation of the forest industries in Nigeria. This can only be achieved through initiation of policy that will enthrone Public-Private-Sector-Partnership in sustainable production of industrial raw materials, most especially, roundwood in the country. The total availability of roundwood of $30 \mathrm{~cm}$ in diameter and above is less than $300,000,000 \mathrm{~m}^{3}$. Thus, Nigeria may run out of industrial roundwood in the next 5 years. As a result, Nigeria must enthrone adequate policies to ensure sustenance of its ndustries most especially, those that have to do with industrial roundwood and wood based panels production. Also adequate policy is required to promote programmes such as wood reuse, environmental planting, development and industrial utilisation of bamboo, formation of forest industry clusters and wood products certification.
\end{abstract}

Keywords: Roundwood, clusters, plywood, certification, wood reclamation.

DOI: $10.7176 / \mathrm{JESD} / 11-16-16$

Publication date:August $31^{\text {st }} 2020$

\subsection{Introduction}

The forest products industry in Nigeria was one of the most developed within the Nigerian economy in the 1960's to early 1970's. During this period, export of wood products and agricultural commodities provided more than 70\% of the country's Gross Domestic Product (GDP). However, the oil glut of the 70's led to gregarious exploitation of round logs for export until its ban in 1976. However, the industry had been experiencing dwindling fortunes since the 1980's. The overexploitation of the forest resources, obsolete equipment, etc combined make Nigeria, a major dependant on the wood resources it was formally exporting. The need to put the industry on a sustainable path became necessary in view of the dwindling fortunes of the country occasioned by the low price of oil in the global market. As a result, it is necessary to critically analyse the dynamics of operations within the sector in order to determine a suitable pathway for its optimal operation in the post COVID-19 pandemic era.

In line with development in most developing countries of Africa, Nigeria's industrialisation strategy is hinged on international cooperation and trade. The pre and post-independence periods up till the COVID-19 pandemic era depended on export of agricultural raw materials and crude oil. These largely erased the gains made towards self-sufficiency in the sourcing of local raw materials within the country and indigenous technology development in the past decades.

The pandemic caused by COVID-19 brought in the worst global health crises in a century, attacking more than 8.7 million people and killing an estimated 480,000 people. This led economies to go on lockdown to slow the spread of the disease and created a demand and supply shocks that greatly affected the world economy resulting in anticipated drops in international trade and investment flows of by about $30 \%$ to $40 \%$ respectively (Solis, 2020). Global trade which was already slowing down in 2019 is being seriously affected in 2020 and the world merchandize trade is set to plummet by between 13 and $32 \%$ by the end of 2020 due to the COVID-19 pandemic. Preliminary analysis of trade data shows that in January - February 2020, major countries imports/exports of wood products including furniture declined, ranging from $6 \%$ (USA) to $27 \%$ in Brazil, year-on-year (FAO, 2020). Among countries experiencing declines were Chile (-24\%), China (-20\%), New Zealand (-17\%), Republic of Korea (-16\%), Japan (-14\% and Canada (-11\%) (FAO, 2020). The dollar value of world merchandize exports in 2019 fell by $3 \%$ to US $\$ 18.89$ trillion. The Organisation of Economic Cooperation and Development (OECD) in its most recent report dated March 2, 2020, downgraded its 2020 real GDP growth projections for almost all economies. The Chinese economy where the virus initially broke out recorded the highest downgrading by $-0.8 \%$ 
as its new forecast growth was put at $+4.9 \%$ from a previous forecast rate of $+5.7 \%$.

The development also impacts negatively on the Nigerian economy. In the first quarter of 2020, the Nigerian economy recorded a slow growth of $+1.87 \%$ (year on year) in real terms. The performance was recorded against the backdrop of significant global disruptions resulting from health crises, a sharp fall in oil prices and restricted international trade. The performance recorded in the first quarter of 2020 represents a drop of $0.23 \%$ points compared to Q1 of 2019 and $0.68 \%$ points compared to Q4 of 2019, reflecting earliest effects of the disruption in economic activities caused by the pandemic.

As nations struggle to satisfy local demands, it became imperative that national security concerns are encroaching on webs of economic interdependence. The pandemic has shown that nations will make strategic concerns to satisfy local demand first. COVID-19 impacts on the international trading system in two specific ways. It reinforced existing trend of reduction and drop in the volume of international trade, the rise of economic security as governments expend their machineries to restrict trade and investment flows, and it has laid bare the fall in USChina relations.

These developments have a lot of implications for sustainable development of Nigeria. The latest economic analysis by the World Bank indicated that managing the impact of the COVID-19 pandemic and the associated oil price shock will require policy options that can help mitigate the effects of the crisis and lay foundations for a strong economic recovery through a stronger partnership that will require government, public and private sector partnerships (World Bank, 2020). This paper examines the dynamics of operations in the forest industry in Nigeria and its ability to provide fulcrum for required accelerated development in view of the high number of employment opportunities it offers. It highlights the current status of the sector, the problems militating against its development and the prospects for its post COVID-19 era recovery.

\subsection{Challenges of the Wood Products Industry in Nigeria}

Nigeria is vastly endowed with abundant forest resources. The present public forest estate which was acquired between 1900 and 1970 embraces $100,000 \mathrm{~km}$ or $11 \%$ of the total land of the country. Only about $26 \%$ of this is in the high forest area. It is estimated that an additional $90,000 \mathrm{~km}^{2}$ or high forest is available outside the forest reserves. The forests have been exposed to unmitigated exploitation. The forest resources have served as engine of growth and propelled economic activities in Nigeria as far back as 1792 when pit sawing operation commenced in Nigeria, followed by the establishment of a power sawmill in Delta area 1902 (Aribisala, 1993). These developments led to substantial increase in wood exploitation for utilization in domestic industries and for export. The wood products sector experienced phenomenal growth that led to establishment of various wood processing industries. Wood export peaked in 1950's with log and sawn wood and subsequently, veneer and plywood. This trend was maintained and sustained in the 1960's and early 1970's. However, by mid-1970's, the toll of intensive exploitation has started showing and volume of wood export which peaked at $700,000 \mathrm{~m}^{3}$, in 1964 , decreased steadily to $290,000 \mathrm{~m}^{3}$, in 1970 (Aribisala, 1993).

A careful study for the vegetation of Nigeria shows that the true protected forest is mainly found in the Southern part of the country where it occupied $93,345 \mathrm{~km}^{2}$ or $9.6 \%$ of the total land area of the country in 1993 . This area increased to $11.4 \%$ in 1994 but dropped to $10 \%$ in $1995(\mathrm{CBN}, 2001)$. Among the factors that led to reduction in forest resources availability is intensive exploitation of the resources. As far back as 1899, the perspective planning for economic development was to exploit forest resources (Adeyoju, 1975). The export revenue from forestry grows at $4.1 \%, 8.0 \%$ and $28.8 \%$ between $1950-60,1960-70$ and $1970-80$ respectively (Aribisala, 1993). The period witnessed the development of a virile forest products industry made up of wellstructured saw mills, wood panel industries, furniture industries, match factories and pulp and paper industries. The sector provides employment opportunities for thousands of Nigerians. The estimate of people engaged in forestry activities ranged from 170,000 in 1933 to 360,000 in 1947 and about 568,000 in 1961 (Adeyoju,1975). By 1983, the estimated number of people involved in various forestry activities has increased beyond 1,000,000 (Oriola, 2009).

However, since the 1970's there have been changes in the structure of the forestry sector occasioned by wood resources overexploitation. The forest resource survey, 1996-1998, revealed that the forest cover has decreased by $20 \%$ over the preceding 18 years. According to Adeyoju (2001), the total forest estate which stood at $10 \%$ of the country's land area in 1996 is now less that 6\%. Ola Adams and Iyamabo (1977) estimated that about 26,000 ha of forest land are destroyed annually in the rainforest zone during the conversion of natural forests to plantation forests and other forms of land use. World Wildlife Fund estimated that over $90 \%$ of the natural vegetation had been cleared and over 350,000 ha of forest and natural vegetations are lost annually (WWF, 1989),

These developments have significant impact on the operations of the forest industries leading to decline in the contribution of forest industries to national industrial development through foreign exchange earnings and products development. Studies by RMRDC (2009) indicated that the total volume of usable wood down to $30 \mathrm{~cm}$ cutting diameter in the forest reserves is $239,775,500 \mathrm{~cm}^{3}$. This is not significantly different from $437,507,205.9 \mathrm{~m}^{3}$ reported by Akindele et al (2001). 


\subsection{Dynamics of Industrial Raw Materials Production in the Forest Industries.}

The forest industry in Nigeria is principally made up of sawmills, furniture and wood based panels subsectors. The performance of each subsector within the industry differs as subsequently discussed.

\subsection{Sawmill Industry}

The installed capacity of the sawmill industry in Nigeria rose from $8,831,750 \mathrm{~m}^{3}$ in 1988 to $15,793,188 \mathrm{~m}^{3}$ in 1992 . It then decreased to $10,900,000 \mathrm{~m}^{3}$ in 1996 and subsequently increased to $14,684,000 \mathrm{~m}^{3}$ in 2002 and $11,734,000 \mathrm{~m}^{3}$ in 2010. In 2020, the installed capacity was estimated at $12,834,000 \mathrm{~m}^{3}$ while capacity utilization was about $28 \%$ (Table 1). The saw mill industry is characterized by small scale operatives who constitute more than $90 \%$ of the entrepreneurs in the sector. A major characteristic of the subsector is increasing number of operatives and decreasing performance. The capacity utilization in the industry is averaged $37 \%$ and the lumber recovery rate 40 - $60 \%$ respectively as a result of obsolete and old equipment. According to Olorunnisola (2000), the annual rate of return is between $15.2 \%$ and $44.3 \%$ while more than $70 \%$ of the workforces are manual labourers. The saw mills used out-dated technologies while only less than $10 \%$ used advance technologies. Although, the sawmill industry has grown from the pit sawing to circular saw head rigs and French manufactured CD4, CD5, CD6 horizontal band saws, mighty mite, brenta vertical, kernali brand, antiglo machine, jevo machine, primultini vertical and forestor, there are only few established saw mills that use the Numeric Controlled (NC) devices. Technological improvement in this industry will impact significantly on log to plank conversion efficiency, most especially now that the diameter of wood from the forests is decreasing daily. Also on decrease is the number of economic wood species that are now available in the forests. Some of the the timber species that were harvested for conversion to planks prior to this period are Mansonia altissima (ofun) Terminalia superba (afara), Tectona grandis (teak), Entandrophragma candollei (omu), Triplochiton scleroxylon (obeche), Entandrophragma cylindricum (sapele), Gossweilodendron balsamiferum (agba), Chlorophora excela (iroko), Khaya ivorensis, Khaya grandifoliola (both are called African mahogany locally) Terminalia ivorensis (edo), Brachystegia spp, Mansonia altissima (makore) and Lophira alata (ekki). Today however, as a result increasing scarcity, the loggers and entrepreneurs are now forced to use wood species formerly regarded as non-economic. A major problem is that the properties of most of the non-economic or lesser used wood species are not fully understood. This militates against international acceptance of their products.

Changes in the raw material characteristics such as decrease in log diameter in Nigerian forests also have a strong influence on conversion efficiency. The short fall in installed capacity and actual capacity utilization occurred as the saw mills are structured to utilized large diameter logs which are now limited in the natural forests as small size timber dominate the present composition of Nigeria's forest resources.

\subsection{Furniture}

Capacity utilization in this industry has been gradually declining. Capacity utilisation in 1985 was $217,700 \mathrm{~m}^{3}$. This increased to $250,714 \mathrm{~m}^{3}$ in 1995 and $236,172 \mathrm{~m}^{3}$ in 2010 . The capacity utilization in 2020 had been estimated to be about $210,000 \mathrm{~m}^{3}$ (Table 2). More than 500 companies exist in this sector while over 10,000 outlets operate at cottage and small scale levels in the informal sector. The large scale companies mostly depend on imported wood composites such as Medium Density Fibreboard (MDF), High Density Fibreboard, etc, while the small scale companies uses the local wood species. The furniture industries in Nigeria date back to 1872 when commercial logging commenced in the country. The evolution of the sector is reflective of the diverse influences that have enriched the countries heritage. While the domestic market for furniture is growing rapidly, the sector has not contributed significantly to foreign exchange earnings as it is dominated by small scale operators of about $3-5$ workmen.

Most operatives in the furniture industry, most especially, the small scale ones uses simple technologies; they have low technical knowhow and low capital input. They are mostly made up of outfits with crude hand tools and equipment, resulting in poor quality products. The small scale furniture producers are technically inefficient as they fall below efficiency level of $60 \%$. The implication is that the average furniture producer need $48 \%$ cost saving devices to attain the status of efficiency, while least furniture producer need about $88 \%$ cost saving devices to become an efficient producer. Most of the small scale operators in this subsector are more interested in quick profit rather than quality control and expansion. Other problems militating against adequate performance of operatives in this subsector are low level of demand, poor workmanship, high level of poverty and long lifespan of furniture products.

\subsection{Plywood and Particleboards}

Plywood production in Nigeria has reduced drastically in the country as a result of high reduction in the volume of economic wood species. Some of the pioneer plywood industry such as Epe Plywood, etc., has closed down, although, some others such as Orbit in Ikorodu have opened, utilization capacity remains low. In 1988, the total capacity was $126,000 \mathrm{~m}^{3}$. This decreased to $106,000 \mathrm{~m}^{3}$ in 2010 . Capacity utilization has decreased further and 
were only $12 \%, 11 \%$ and in 2010 and 2020 respectively (Table 3 ). Face veneer is in short supply as one of the major producers; the government owned African Timber and Plywood is only operating skeletally. Other problems of Face veneer producers are old equipment and lack of spare parts. Capacity utilization in the particleboard industry was $12,900 \mathrm{~m}^{3}$ and $11,496 \mathrm{~m}^{3}$ respectively in 2002 and 2010 respectively (Table 4). Current production is hampered by high cost of production, resulting primarily from high cost of imported resins and old equipment.

\subsection{Industrial Roundwood Production}

Industrial roundwood in Nigeria comes mostly from the natural high forest zone of the country, in particular from the southern states of Cross River, Edo, Ogun, Ondo and Oyo States of Nigeria. Roundwood includes industrial roundwood, poles and fuelwood. In general, the demand for industrial had been increasing in the country. In 1995 , the demand for industrial roundwood was $113,602,000 \mathrm{~m}^{3}$. This increased to $126,602,000 \mathrm{~m}^{3}$ in 2000 and subsequently to $153,008,458 \mathrm{~m}^{3}$ and $180,008,000 \mathrm{~m}^{3}$ in 2010 and 2020 respectively (Table 5). The industrial roundwood required by other subsectors of the wood and wood sector are also highlighted in the table.

Presently, there is general shortage of roundwood. In 1998 Forest Resource Study puts the volume of industrial roundwood at $268.7 \mathrm{~m}^{2}$ for all forest types. The estimated total roundwood production in 2003 was 69.9 million $\mathrm{m}^{3}$ of which 60.4 million $\mathrm{m}^{3}(86 \%)$ was fuelwood (FAO, 2005). The continued and sustained level of roundwood consumption in Nigeria is a threat to the forest estate and a source of deforestation which is now a threat. This stresses the need to embark on aggressive afforestation. The situation is more critical as most of the mills cannot handle small sized logs. This has affected availability of various solid hardwoods, most especially the prime ones.

\subsection{Import of Wood and Wood Products in Nigeria (2016 - 2019)}

Nigeria has been a major consumer of processed secondary wood products. To promote development of local industries, a number of secondary raw materials are imported on annual basis. Table 6 shows the figure of imported wood articles between 2016 - 2019. More than 1 trillion naira was expended on importation of various sizes of plywood with different HS Codes. For HS Code 4408900000 (veneer sheets and sheets for plywood), more than $166,346.56 \mathrm{~kg}$ worth was imported between 2016 - 2019, culminating in an expenditure of about $\$ 443$ billion. Within the same period, Oriented Strand Board with HS Code 44110120000 of about 329,753,36kg was imported value at $\$ 68$ billion were imported into the country. The cost for importation of particleboard of various HS Codes is also shown. Within 2016 - 2019, particleboards worth more than 780 billion naira were imported (Table 7).

Within the same period, bamboo products of various HS Codes were also imported. Bamboo products with HS Code 4412100000 which include block board, laminboard and bathenboard worth $\$ 22$ billion were imported between 2016 to 2019. In addition, bamboo plywood, veneer panels and similar laminated wood of about $61,000.63 \mathrm{~kg}$ that worth $\$ 85$ billion were imported into the country amongst other bamboo products (Table 8 ). These developments underscore the need to develop local raw materials for use by our industries in the country.

\subsection{Prospects for Post COVID-19 Era Development of the forest industries}

Nigeria has a number of opportunities to develop forest products industry to the level it deserves if adequate policy options are instituted. Some of the options are currently being pursued by relevant agencies. However, the need for a more comprehensive approach backed by adequate policy, fund and high level monitoring of compliance should be a post COVID-19 era imperative. Some of these are discussed below.

\subsection{Industrial Roundwood Production}

It has become mandatory that the production of industrial roundwood be stepped up. This project must be maintained and sustained in Nigeria if the wood industry is not to experience collapse in the immediate future as Nigeria is now a net importer of roundwood (FAO, 2005). The country has institutions such as the Forestry Research Institute of Nigeria that has the mandate of producing planting materials of indigenous economic wood species. Also there are biotechnology outfits that belong to both private investors and the government. The major problem is funding. Less than 1\% of Nigeria's budget goes to R\&D. The funding of research most especially on production of improved planting materials must be increased as a matter of policy. In most cases, the Ministry of Natural Resources in the States are mostly interested in revenue that comes from the forest. It is imperative that government should cede some of the land to private sector operatives who in most cases will be willing to participate in plantation establishment even within the forest reserves.

One of the major problems facing Nigerian forestry is inadequate funding. In 1993, the Federal Government urged State Governments to pay $10 \%$ of forestry revenues in a trust fund for forest management. However, only a few State governments implemented this proposal. This fund would have been very ideal for plantation establishment. Closely allied with plantation establishment of economic indigenous wood species, it is also 
important that communities be educated on the need to establish fuelwood plantations. About $50 \%$ of industrial roundwood produced in Nigeria are used as fuelwood and charcoal. Deliberate efforts must be made to ensure that wood species for industrial applications are not felled and used for charcoal and fuelwood production.

The Raw Materials Research and Development Council has a programme designed to promote plantation establishment of economic indigenous wood species. The primary objective of the programme is to promote industrial wood supply and afforestation in collaboration with private sector operatives. The Council collaborates with both private sector organisations to establish industrial plantations through the provision of improved seeds.

\subsection{Enrichment Planting}

The tropical rainforest ecosystem is the most complex in structure and richest in species composition. The report observed that about 5000 direct benefits of commercial forest products could be obtained from the forests worldwide. About $80 \%$ of human food supply is obtained from just about 20 types of plants (Myers, 1990). The high utilization potentials of these natures' resources have led to intense pressure to which they have been subjected to for centuries. The long term effect of this high dependence has led to their destruction in terms of quality and quantity. Onyekwelu and Afuwape (2008) pointed out that Nigeria's tropical rainforest has been heavily exploited, seriously degraded and fragmented, leaving about 5\% of the country's rainforest ecosystem undisturbed. As forest degradation is usually accompanied by reduction in species diversity, decrease in primary productivity, change in forest structure and depletion in soil nutrients (Abubakar, 2010), the species diversity of the Nigerian rainforest ecosystem has decreased substantially. One strategy for combating forest degradation and enhancing the value of forests is to increase the concentration of economically important indigenous tree species by planting seeds in degraded forests (enrichment planting) for future harvest (Lawal and Adekunle, 2011). Consequently enrichment planting can lead to restoration of biodiversity of degraded tropical forests (Adekunle, 2006). Thus the need to intervene in most forests in Nigeria has necessitated that investment should be promoted in this area.

\subsection{Agroforestry Practices}

Agroforestry is the practice of growing trees and agricultural products on the same plot at the same time. It helps farmers create more integrated, diverse, productive, profitable, healthy and sustainable land use systems. It also provides environmental, economic and social benefits to land owners, and/or producers (Kortand Turnock, 1998). Agroforestry encompasses a very large and diverse set of practices ranging from cropland in which a minimum tree component is added to complex forest production that has been integrated into an existing forest structure. Agroforestry practices have the capability of increasing wood supply to the forest industries.

\subsection{Solar Energy Tapping and Utilization}

Industrial and domestic solar trapping and utilization have been touted as one of the major options for mitigating deforestation globally. In Nigeria, Bala et al (2000) reported that average daily sunshine is 6.25 hours. This ranges between 3.5 hours in the coastal areas to 9.0 hours at the far northern boundary. The average daily solar radiation has also been reported to be about $5.25 \mathrm{kw} / \mathrm{m}^{2} /$ day by Bala et al. (2000). The daily solar radiation varies between $3.5 \mathrm{kw} / \mathrm{m}^{2} /$ day at the coastal area and $7.0 \mathrm{kw} / \mathrm{m}^{2} /$ day at the northern boundary. According to Adegoke et al. (2011), Nigeria receives $4.851 \times 10^{12}$ of energy per day from the sun. This is equivalent to about 1.082 million tonnes of oil equivalent (mtoe). This is about 4000 times than current daily crude oil production and about 13,000 times that of natural gas production based on energy unit. The annual solar energy insolation value is about 27 times the total conventional energy resources and over 117,000 times amount of electric power generated in the country in 1998 (Chendo, 2002). Based on the average land area of the $924 \times 10$ $\mathrm{km}^{3}$, for the untry, only about $3.7 \%$ of the total land area is needed to be utilized in order to collect from the sun and amount of energy equal to the nation's energy conventional reserve. Production of electric power from solar energy is not a new technology. It has been domesticated in some tertiary institutions in Nigeria and inadequacy can be perfected and upgraded. Thus, this can be a virile investment for private sector operatives locally with adequate policy initiative and guidelines locally. In view of inadequacy of energy infrastructure in Nigeria, forest industries can embark on solar trapping and utilization for industrial operations.

\subsection{Bamboo Development and Utilization}

Bamboo grows in 23 States of the Federation. Most of these States, most especially, those in South East, South West, South-South and North Central can support viable bamboo processing enterprises. According to FAO (2012), the total volume of bamboo growing in Nigeria is about $460,000,000 \mathrm{~m}^{3}$ while the total volume of industrial roundwood is less than $400,000,000 \mathrm{~m}^{3}$. Bamboo grows very fast and reaches matures in about 4 years. It has multifunctional applications. It is used in chemical, pharmaceutical, wood, pulp and paper, textiles, building and construction industries. In China, bamboo processing is highly commercialised and contributes more than $\$ 5$ billion to the Chinese economy on annual basis. Currently in Nigeria, bamboo is mostly used in the building 
industry for scaffolding and in farms as yam stakes.

To optimise forest industries development in the Post COVID-19 era, a deliberate policy directed at promoting industrial processing of bamboo in the sector has become important. In the short to medium term, bamboo culms can replace wood in most applications before the industrial roundwoods matures. To optimize development in the forest industry, there is need for the establishment of factories producing bamboo based panels. The panels are manufactured under high temperature and pressure with the aid of adhesives. The thickness of bamboo based panels varies from $2-40 \mathrm{~mm}$ and the dimensions depend on the manufacturing equipment adopted. The main feature of its manufacturing technology is high temperature softening and flattening (Qisheng et al, 2002). It can be sawn, planed, milled, dried and used for further processing, thereby making it a comparatively ideal material for engineering structure (Qisheng et al, 2002) such industries should be treated as pioneer industries. Ply bamboo is used in truck floors as weight of steel materials is too high. In addition ply bamboo has high friction coefficient and it does not rust. Also production of laminated bamboo board (planed) is very essential. During the production of laminated bamboo, bamboo materials are cut into square edge strips of even thickness and width. The strips are bleached or carbonized. They are arranged in one direction during assembling and pressed. The products are multilayered and of great dimension. The surface is fine grained and can be used in furniture production and in inner decoration, just as in laminated high grade wood. Other important bamboo products required in the wood industry are mat ply bamboo; curtains ply bamboo, laminated wood strips, mat curtain plywood, bamboo chipboard, floor tiles and composites (Ogunwusi, 2012a).

\subsection{Utilisation of Adequate Processing Facilities}

One of the banes of wood processing industry in Nigeria is utilisation of substandard equipment. There is need for provision of standard process equipment for production of components and products to international standard (GWV 1994). The hand and un-powered tools currently employed by small scale entrepreneurs are out place in modern wood processing industries. In the furniture companies for instance, the basic equipment are seasoning kilns, wood treatment plants, plaining machinery, etc. The Raw Materials Research and Development Council in collaboration with the Scientific Equipment Development Agency (SEDI) Enugu have designed and fabricated two types of wood seasoning kilns which should be commercialised for use in the sector. Special intervention funds for the procurement of equipment and machinery could be obtained from funding institutions, cooperatives and government agencies such as Raw Materials Research and Development Council or raised by the associations involved.

\subsection{Establishment of Wood Reclamation Centres}

The need to initiate and institute the culture of wood reclamation in Nigeria has become important in view of the high wastage that occurs during disposal of used woods during renovation of houses, government offices, etc., in Nigeria. As a result, appropriate Ministries and Agencies should be mandated to collaborate with the private sector to actualise this.

Wood wastes generated from households come mainly from furniture, fencing, floorboards, kitchen items, etc. Although figures are not available in Nigeria, Environment Resources Management (2012) estimated that the United Kingdom produces about 7.5 million tonnes of municipal, industrial and commercial wood wastes in addition to construction and demolition wastes annually. Only about $16-20 \%$ of the wood wastes are being reused, recycled, or channelled for energy recovery. .

Currently, more than 12 million tonnes of wood wastes are used in landfill every year. This is dangerous for several reasons. One of the major reasons is that landfills contribute significantly to land water and air pollution. The second is that the demand for wood is on the increase globally and large areas of primary forests are cut down to meet the rising demand for timber. This is leading to large scale deforestation which is responsible for a significant part of the present climate change problems (ITTO, 2005).

\subsection{Promotion of Wood Products Certification}

According to Ghazali (2012) certification is designed to allow consumers to select products made from timber from sustainably managed forests. This is a way of reducing competitiveness of illegally harvested wood in the international market. The 1992 United Nations Conference on Environment and Development (UNCED) emphasized the need for sustainable management guidelines, criteria and indicators for temperate, boreal and tropical forests alike. At UNCED, over 120 countries agreed, in the Forest Principles (which applies to all types of forests), that forest resources and forest lands should be maintained to meet the social, economic, ecological, cultural and spiritual needs of present and future generations.

Timber certification is a process which results in a written statement (a certificate) attesting to the origin of wood raw material and its status and/or qualifications, often following validation by an independent third party. Certification is designed to allow participants to measure their forest management practices against standards and to demonstrate compliance with those standards. Timber certification may also be used to validate any type of 
environmental claim made by a producer, or to provide objectively stated facts about the timber products and their forest of origin that are not normally disclosed by the producer or manufacturer. Timber certification typically includes two main components: certification of sustainability of forest management; and product certification. Certification of forest management covers forest inventory, management planning, silviculture, harvesting, road construction and other related activities, as well as the environmental, economic and social impacts of forest activities. In product certification, roundwood and processed timber products are traced through the successive phases of the supply chain. Certification would discourage export of illegally harvested logs and discouraged such practices (Ghazali, 2012).

\subsection{Formation of forest Industry Clusters}

In the $21^{\text {st }}$ century, one of the major ways of encouraging small scale industries to perform optimally is to put them in clusters. Clusters can be defined as a group of business enterprises and non-business organisations for whom membership within the group is an important element of each member firms individual competitiveness (Bergman and Feser, 2011). Binding the cluster together are buyer - supply relationships or common technologies, common buyers or distribution channels or common labour pools (Enright, 2000). In most cases, non-business associations such as industry associations, technical and community colleges with specialized industry programmes, universities, government industrial extension programmes, commonly referred to as critical related supporting institutions are often part of the cluster.

The industrial cluster concept dates from the last century and has captured the imagination of policy makers, scholars and governments in the last decade. In many countries, the formation of industrial clusters has led to the success of several industries in the global market. According to Yamawaki (2001) the evolution of industrial clusters is brought about by a variety of circumstances ranging from existence of industries to technology transfer from other clusters, availability of a pool of workers, foreign technology input, import substitution and creation of new infrastructure. The furniture cluster in Morodomi in Saga prefecture in Japan was formed as a result of a toll bridge built over Chikugo River connecting Ohakwa and Morodomi at the point where furniture producers at Ohakwa were searching for new locations to expand their manufacturing base (Yamawaki, 2001).

The primary objective of establishing a furniture industrial cluster is to remove isolation and barriers that have eliminated profitability of small scale furniture enterprises in Nigeria. In line with UNIDO (2006), the purpose will be to encourage small scale furniture makers which are located in close proximity to come together as a group to promote their rapid economic growth, efficiency, production of high quality products for export, employment generation and creation and preservation of high value added jobs. Consequently, existing small scale furniture producing outfits should be pooled to form associations on local and regional basis. For optimal achievement of the objective of the formation of the clusters, there is need for the association involved in a cluster to provide standard process equipment for production of furniture components to international standard (GWV 1994). Special intervention funds for the procurement of equipment and machinery could be obtained from funding institutions, cooperatives and government agencies. Each business outfit within the cluster will use the facilities at standard costs.

Closely allied with this is training and innovation. The primary objective of training small scale furniture makers in the cluster will be to promote the design of exotic state of art furniture among them. This will necessitate a paradigm shift in the business of designing and manufacturing of quality wood products. According to OyelaraOyeyinka and Lal (2006) an increase of $1 \%$ in the number of trained workers potentially increase value added or firms by as much as $60 \%$. There is also need for contacts with research institutes such as Forestry Research Institute of Nigeria or its outstations on design and products improvement. This is necessary as the supply base of prime wood is depleting and the need for complementary use of alternative raw materials is becoming important. Research on appropriate treatment methods, innovations on optimal utilization of solid wood and wood wastes are also imperative. In most cases, innovations should be directed towards cost reduction and competition (NACETEM, 2010). Also research and training institutions should help sustain perpetual research and innovation necessary to continuously generate new products and open new markets (Hertug, 1999). Already in Nigeria, Oyebisi et al (1996) reported that industry-university interaction do exist, but at low levels. This type of interaction is important to enable clusters internalize knowledge developed elsewhere (Rosa and Mohnen 2008).

There is also need for development of marketing outlets for the products of the industrial clusters. High quality hardwood furniture produced to international specification and standards will find market in most developed countries. There is also need for development of a comprehensive marketing consultancy for all the products within the cluster so as to ensure that the products are marketed professionally.

Cluster authorities should provide relevant infrastructure such as energy, road and water within the cluster. This is imperative as energy generation by government agencies has proved unreliable over the years. The procurement, installation, servicing and fuelling of generators for day to day running of operatives should be handled centrally to optimize efficiency. Successful operation of regional clusters may attract funding agencies and banks, etc., as impediments associated with individual ownership have been removed. 


\subsection{Conclusion}

The negative impacts of the COVID-19 crises on the production and trade of forest products is putting industries that depend mainly on importation of raw materials at very great risk. This is mainly due to collapse of most of the industries producing secondary raw materials as a result of scarcity of prime industrial roundwood. Reinforcing efforts for more sustainable production of forest product, most especially industrial roundwood will provide avenue for sustaining the development of Nigerian wood and wood products sector. This is also very important and vital towards building on progress made towards the 2030 Agenda for sustainable development.

The need to exploit other alternatives for the development of this sector has become highly imperative. A major alternative is the development and industrial utilisation of bamboo. Bamboo processing enterprise will not only assist in the development of most subsectors of the forest industry, it will lead to expansion of the sector and promote foreign exchange generation and employment opportunities.

Other imperatives needed for sustainable development of this sector include wood reclamation, certification of $\operatorname{logs}$, formation of industrial clusters and reduction in the volume of fuelwood used locally. Also exportation of charcoal should be reduced or banned to reduce incidence of converting industrial wood to charcoal for export.

\section{References}

Abubakar. H.T. (2010). Many species, one planet, one future. A keynote address. In Ofoezie,I. E. , .A.Awotoye , $\mathrm{OO}$ and Adewole, M. B. (eds). Proceedings of the third annual conference of thje Institute of Ecology and Environmental Studies. OAU, Ile Ife Nigeria. June $15^{\text {th }}-17^{\text {th }}, 2010$.

Adegoke, I.A., Adejoba, O.R., Ogunsanwo, O.I. and Ayodele, O.O. (2011). Contribution of renewable energy in ensuring environmental sustainability in Nigeria. . In L. Popoola, K Ogunsanwo and F. Idumah (eds) Foresrty in the next millennium and development goals. Proceedings of the $34^{\text {th }}$ Forestry Association of Nigeria, Osogbo, Osun State Nigeria. Pp 315-321.

Akindele, S.O, Dyck.J.,Akindunmi, F.F,Papka, P.M, and Olaleye, O.A. (2001) Estimate of Nigeria`s Timber Resources. In L Popoola, J.E. Abu and P.I Oni (ed.) Proceedings of the $27^{\text {th }}$ Annual Conference of the Forestry Association of Nigeria, Abuja FCT. Pp1-11

Aribisala, A. O. (1993): Raw Materials Revolution and Impact on Industrialisation in Nigeria. Mednet Publications Ltd. (1993). ISBN 978 - 024 - 000 - 4

Brown, N., Jennings , S and Clements, T., (2003). The ecology,silviculture and biogeography of Mahogany (Swietenia macrophyla: a critical rewiev of the evidence. Perspectives in plant ecology, Evolution and Systematics6: 39-49.

Chendo, M.A.C. (2002). Factors militating against the growth of the Solars-PV industry in Nigeria and their removal. Nigerian Journal of Renewable Energy 8(1\&2): 151-158.

Dawkins, H.C and Phillips, M.S. (1998). Tropical moist silviculture and management. History of success and failure. CAB International, New York.

Deutsch, J. (2007). Regional action plan for conservation of the Cross River Gorilla. Environment News Service, New York, June 21.

Dixon, R.K. (1995)Agroforestry systems:Sources or sinks of green house gases?. Agroforestry Systems31: 99-116

Environmental Resources Management (ERM) (2012). Wood Waste Facts.

FAO (1979): Forest Development, Nigeria Development alternatives for Forest resources. Technical Report 2, FO:SF/NIR/546 UNDP/FAO.

FAO, (2005). Microfinance and Forest-based Small-Scale Enterprises, p. 246, FAO, Rome.

Fay, C., H. Deforeya., M. Sarait and T.P. Tomich (1998). A policy breakthrough for Indonesian farmers in the Krui Dammer . Agroferesters Today. 10(2):25-26.

FDF (1984): Nigerian Forestry Statistics: Compiled by Khalique, U.R. and Aruofor, R.O. FOR/MEU/STAT/PUB No. 2 Federal Department of Forestry, Lagos.

FDF (1996): Nigerian Forestry Action Programme. Federal Department of Forestry, Abuja.

FDF (1998a): Nigeria Forest Resources Study; Federal Department of Forestry Abuja.

Federal Department of Forestry (FDF) And Federal Ministry of Environment (FME) (1999). Approved Forestry Development Plan. FDF\&FME: 27-53.

Federal Republic of Nigeria Forestry Sector Review Report No. 10744 - UNI Fed. Dep. of Forestry, Abuja.

Ghazali, B.H. (2012): Timber Certification. An Overview

Hakkila, P. and Parikka, M. (2002). Fuel resources from forest . In: Bioenergy from Sustainable Forestry: Guiding Principles and Practice (eds) J. Richadson, R. Bjorheden, P Hakkila, A.T. Lowe and C.T Smith. Kluwer Press, The Netherlands http://www.woodrecycling.org.uk/info_woodfacts.html. Assessed November 7, 2012. ITTO (2005). Status of Tropical Forest Management 2005. ITTO Technical Series No.2 4.

Kort., J. and Turlock R. (1999). Carbon reservoir and biomass in Canadian Priere shelterbelts. Agroforestry syatems. 44:175-189

Lawal, A. and V.A. J. Adekunle (2011). Impact of enrichment planting on biodiversity restoration in degraded 
forest. In L. Popoola, K Ogunsanwo and F. Idumah (eds) Forestry in the next millennium and development goals. Proceedings of the $34^{\text {th }}$ Forestry Association of Nigeria, Osogbo, Osun State Nigeria. Pp 558-571.

Nigeria: Forestry Sub-sector review. IBRD/World Bank; Western Africa Region Projects Department. Federal Department of Forestry, Ibadan.

Ogunwusi, A.A. (2012). Imperatives and Guidelines for Bamboo Development Policy in Nigeria. Journal of Research in Industrial Development 10(2b): 348-357.

Ola-Adams, B.A. and Iyamabo D.E. (1977) Conservation of Natural Vegetation of Nigeria: Environment Conservation 4(3): 217-226.

Oladeji, J.T,. Enweremadu, C.C and Olafimihan, E.O. (2009). Conversion of Agricultural residues into biomass briquettes. JAAAR 5(2):116-123.

Oladeji, J.T. (2010). Fuel characterization of briquettes produced from corncob and rice husk residues. Pacific Journal of Science and Technoligy.11 (1)101-106.

Olorunnisola, A.O (2000): Workshop Structure in the small Scale Furniture Industry in Ibadan metropolis. Journal of Tropical Forest Resources 16(1):46-57.

Olorunnisola, O. A. (2000). Workshop Structure in Small Scale Furniture Industry in Ibadan Metropolis. Journal of Tropical Forest Resources 16(i) : $46-57$.

Oriola E.O (2009). Forestry for Sustainable Development In Nigeria. International Journal of African Studies. ISSN 1451-213X Issue 1 pp 11-16.

Oyebisi, T. O; Ilori, M. O and Nassar, M. L (1996) Industry-Academic relations;an assessment of linkages between university and some enterprises in Nigeria. Technovation 16(4) 1996 pp 203-209.

Oyelara-Oyeyinka, B., and LAL, k. (2006) SME's and New Technologies, Learning E-business and Development.UK. Palgrave Publishers.

UNIDO (2006). SME Cluster and Network Development: Principles and Practice, United Nations Industrial Development Organisation (UNIDO), 2006.

World Bank (2020): Nigeria Development Update: Rebuilding After CORVID-19 https://www.worldbank.org/en/country/nigeria/publication

Yamawaki, H. (2001). Evolution and Structure of Industrial Clusters in Japan. The International Bank for Reconstruction and Development/The World Bank. Stock No 37183. 2a pp.

Table 1: Installed Capacity and Capacity Utilisation in Forest Industries in Nigeria

\begin{tabular}{|c|c|c|c|c|}
\hline Year & No. of Sawmills & Total Installed Capacity & $\begin{array}{c}\text { Utilisation } \\
\text { capacity }\end{array}$ & $\begin{array}{c}\text { Capacity } \\
\text { Utilisation \% }\end{array}$ \\
\hline 1985 & 910 & $8,831,750$ & $6,994,660$ & $79 \%$ \\
\hline 1995 & 1,250 & $10,900,000$ & $4,200,000$ & $39 \%$ \\
\hline 2000 & 1,259 & $14,684,000$ & $5,177,700$ & $35 \%$ \\
\hline 2010 & 1,325 & $11,734,000$ & $3,800,000$ & $32 \%$ \\
\hline 2020 & 1,425 & $12,834,000$ & $3,650,000$ & $28 \%$ \\
\hline
\end{tabular}

Table 2: Installed Capacity and Capacity Utilization (round log equivalent) in the Furniture Industries

\begin{tabular}{|c|c|c|c|c|}
\hline Year & No. of Industries & $\begin{array}{c}\text { Total Installed } \\
\text { Capacity }\end{array}$ & $\begin{array}{c}\text { Utilisation } \\
\left.\text { capacity } \mathbf{( m}^{\mathbf{3}}\right)\end{array}$ & $\begin{array}{c}\text { Capacity } \\
\text { Utilisation } \%\end{array}$ \\
\hline 1985 & 5,000 & N/A & 217,000 & N/A \\
\hline 1995 & 10,000 & N/A & 250,714 & N/A \\
\hline 2000 & 10,000 & N/A & N/A & N/A \\
\hline 2010 & 11,000 & N/A & 236,172 & N/A \\
\hline 2020 & 11,250 & N/A & 210,000 & \\
\hline
\end{tabular}

Table 3: Installed Capacity and Capacity Utilization in the Plywood Mills

\begin{tabular}{|c|c|c|c|c|}
\hline Year & No. of Plywood Mills & $\begin{array}{c}\text { Total Installed } \\
\text { Capacity } \mathbf{~ m}^{\mathbf{3}} / \mathbf{y r} .\end{array}$ & $\begin{array}{c}\text { Utilisation } \\
\text { capacity } \mathbf{~ m}^{\mathbf{3}} / \mathbf{y r} .\end{array}$ & $\begin{array}{c}\text { Capacity } \\
\text { Utilisation } \%\end{array}$ \\
\hline 1985 & 8 & 126,000 & 67,340 & $53 \%$ \\
\hline 1995 & 10 & 126,000 & 54,600 & $43 \%$ \\
\hline 2000 & 4 & 106,000 & 14,900 & $14 \%$ \\
\hline 2010 & 2 & 96,000 & 10,250 & $11 \%$ \\
\hline 2020 & 4 & 120,000 & 14,350 & $12 \%$ \\
\hline
\end{tabular}


Table 4: Installed Capacity and Capacity Utilization in the Particleboard Industries

\begin{tabular}{|c|c|c|c|c|}
\hline Year & No. of Particleboard Mills & $\begin{array}{c}\text { Total Installed } \\
\text { Capacity } \mathbf{~ m}^{\mathbf{3} / \mathbf{y r} .}\end{array}$ & $\begin{array}{c}\text { Utilisation } \\
\text { capacity } \mathbf{~ m}^{\mathbf{3}} \mathbf{\text { yr. }}\end{array}$ & $\begin{array}{c}\text { Capacity } \\
\text { Utilisation \% }\end{array}$ \\
\hline 1985 & 2 & 85,000 & $\mathrm{~N} / \mathrm{A}$ & $\mathrm{N} / \mathrm{A}$ \\
\hline 1995 & 4 & 67,150 & 54,600 & $81 \%$ \\
\hline 2010 & 4 & 45,000 & 11,496 & $26 \%$ \\
\hline 2020 & 2 & 22,000 & 4,350 & $12 \%$ \\
\hline
\end{tabular}

Table 5: Forecasts for Demand for Round Wood $\left(1985\right.$ - 2020) (in 1000) $\mathrm{m}^{3}$

\begin{tabular}{|c|l|c|c|c|c|c|c|}
\hline S/N & \multicolumn{1}{|c|}{ Type } & $\mathbf{1 9 8 5}$ & $\mathbf{1 9 9 5}$ & $\mathbf{2 0 0 0}$ & $\mathbf{2 0 1 0}$ & $\mathbf{2 0 2 0}$ & Source \\
\hline 1. & $\begin{array}{l}\text { Industrial Roundwood } \\
\text { include } \\
\text { Roundwood, Industrial } \\
\text { Fuelwood }(1000) \mathrm{m}^{3}\end{array}$ & - & 113,602 & 126,887 & 153,458 & 180,008 & FDF 2000 \\
\hline 2. & Fuel Wood & - & 93,544 & 104,244 & 125,644 & 147,044 & FDF 2000 \\
\hline 3. & Industrial Round Wood & - & 7,524 & 7,524 & 7,524 & 7,524 & FDF 2000 \\
\hline 4. & Saw Log & - & 598 & 1,073 & 2,118 & 2,973 & FDF 2000 \\
\hline 5. & Fuel Wood & - & - & 128,495 & 156,634 & - & Gen Woods 1994 \\
\hline 6. & Saw Log & - & - & 7,558 & 10,935 & - & Gen Woods 1994 \\
\hline 7. & Veneer Log & - & - & 618 & 618 & - & Gen Woods 1994 \\
\hline 8. & Fuel Wood & - & - & 109,966 & 111,102 & - & IBRD 1992 \\
\hline 9. & Poles & - & - & 2,874 & 3,441 & - & IBRD 1992 \\
\hline 10. & Saw Log & - & - & 4,199 & 6,432 & - & IBRD 1992 \\
\hline 11. & Veneer Log & - & - & 858 & 1,359 & - & IBRD 1992 \\
\hline
\end{tabular}

Table 6: Import of Wood and Articles of Wood, Wood Charcoal (Hs Code 44) from 2016 - 2019

\begin{tabular}{|c|c|c|c|c|c|c|}
\hline \multirow{2}{*}{ HS CODE } & \multirow{2}{*}{ DESCRIPTION } & 2016 & 2017 & 2018 & 2019 & $\begin{array}{l}\text { GRAND } \\
\text { TOTAL }\end{array}$ \\
\hline & & Value (N) & Value (N) & Value (N) & Value (N) & $\begin{array}{c}\text { Value } \\
(\mathrm{N}) / \text { Billion }\end{array}$ \\
\hline \multirow[t]{2}{*}{4408900000} & $\begin{array}{l}\text { Veneer sheets and sheets } \\
\text { for plywood and }\end{array}$ & 8247971.42 & NA & 11916122.17 & NA & 20164093.59 \\
\hline & $\begin{array}{l}\text { Veneer sheets and sheets } \\
\text { for plywood and other } \\
\text { wood, }=<6 \mathrm{~mm} \text { thickness }\end{array}$ & NA & NA & 20588243.83 & 23725066.31 & 44313310.14 \\
\hline 4410120000 & $\begin{array}{l}\text { Oriented strand board } \\
\text { (OSB) }\end{array}$ & 17339730.44 & 16934753.44 & 18983205.00 & 15724188.07 & 68981876.95 \\
\hline \multirow[b]{2}{*}{4410190000} & $\begin{array}{l}\text { Other Particle board, } \\
\text { oriented strand board }\end{array}$ & 14114348.66 & 9518635.45 & 860957.73 & NA & 24493941.84 \\
\hline & $\begin{array}{l}\text { Other Particle board, } \\
\text { oriented strand board } \\
\text { (OSB) and similar board } \\
\text { not specified. }\end{array}$ & NA & NA & 5329917.37 & 13190064.17 & 18519981.54 \\
\hline \multirow{3}{*}{4410900000} & $\begin{array}{l}\text { Particle board and } \\
\text { similar board (for ex }\end{array}$ & 23811693.03 & 4301376.60 & 7916790.15 & NA & 36029859.78 \\
\hline & $\begin{array}{l}\text { Particle board and } \\
\text { similar board (for ex } \\
\text { Other }\end{array}$ & NA & NA & 8962528.08 & 13427638.59 & 22390166.68 \\
\hline & $\begin{array}{l}\text { Particle board and } \\
\text { similar board of ligneous }\end{array}$ & 3003370.00 & 5599815.00 & NA & NA & 8603185.00 \\
\hline \multirow{2}{*}{4411120000} & $\begin{array}{l}-- \text { Of a thickness not } \\
\text { exceeding } 5 \mathrm{~mm} \text {. }\end{array}$ & 116233060.00 & 93999578.50 & 25318993.50 & NA & 235551632.00 \\
\hline & $\begin{array}{l}\text { Of a thickness not } \\
\text { exceeding } 5 \mathrm{~mm}\end{array}$ & 19728370.21 & 32602412.03 & 44383900.09 & 25454098.23 & 122168780.56 \\
\hline \multirow[b]{2}{*}{4411130000} & $\begin{array}{l}\text { Of a thickness exceeding } \\
5 \mathrm{~mm} \text { but not }\end{array}$ & 17375289.21 & 24615961.50 & 27289715.52 & NA & 69280966.23 \\
\hline & $\begin{array}{l}\text { Of a thickness exceeding } \\
5 \mathrm{~mm} \text { but not exceeding } \\
9 \mathrm{~mm}\end{array}$ & NA & NA & 20032103.83 & 33220679.31 & 53252783.15 \\
\hline \multirow{2}{*}{4411140000} & $\begin{array}{l}\text {-- Of a thickness not } \\
\text { exceeding } 9 \mathrm{~mm} \text {. }\end{array}$ & 13922129.00 & 49672330.78 & 51179992.78 & NA & 114774452.56 \\
\hline & $\begin{array}{l}\text { Of a thickness exceeding } \\
9 \mathrm{~mm}\end{array}$ & 15150336.70 & 25257526.64 & 21386338.23 & 30437841.47 & 92232043.03 \\
\hline
\end{tabular}




\begin{tabular}{|c|c|c|c|c|c|c|}
\hline \multirow{2}{*}{4411920000} & $\begin{array}{l}\text {-- Of a density exceeding } \\
0.8 \mathrm{~g} / \mathrm{cm} 3\end{array}$ & 9860945.40 & 28099080.50 & NA & 32013251.33 & 69973277.23 \\
\hline & $\begin{array}{l}\text { Of a density exceeding } \\
0.8 \mathrm{~g} / \mathrm{cm} 3\end{array}$ & 31002945.97 & 25839857.81 & 36264748.11 & NA & 93107551.88 \\
\hline \multirow[t]{2}{*}{4411930000} & $\begin{array}{l}\text { Of a density exceeding } \\
0.5 \mathrm{~g} / \mathrm{cm} 3 \text { but not }\end{array}$ & 4168124.81 & 19582418.11 & 62601626.88 & NA & 86352169.80 \\
\hline & $\begin{array}{l}\text { Of a density exceeding } \\
0.5 \mathrm{~g} / \mathrm{cm} 3 \text { but not } \\
\text { exceeding } 0.8 \mathrm{~g} / \mathrm{cm} 3\end{array}$ & NA & NA & 1106078.32 & 2294359.35 & 3400437.67 \\
\hline 4411940000 & $\begin{array}{l}\text { Of a density not } \\
\text { exceeding } 0.5 \mathrm{~g} / \mathrm{cm} 3\end{array}$ & 17708186.71 & 8850352.80 & 47740849.44 & 9059250.80 & 83358639.74 \\
\hline 4412100000 & Of bamboo & 7099883.08 & 11899082.00 & 2709996.13 & NA & 21708961.21 \\
\hline \multirow[b]{2}{*}{4412310000} & $\begin{array}{l}\text { With at least one outer } \\
\text { ply of tropical wood }\end{array}$ & 3549940.00 & 232.00 & 2036755.00 & 4734796.53 & 10321723.53 \\
\hline & $\begin{array}{l}\text { With at least one outer } \\
\text { ply of tropical wood } \\
\text { specified } \mathrm{i}\end{array}$ & NA & NA & 7790112.14 & 10679982.69 & 18470094.83 \\
\hline \multirow[b]{2}{*}{4412320000} & $\begin{array}{l}\text {-- Other, with at least } \\
\text { one outer ply of }\end{array}$ & 7014776.00 & 23392083.93 & 22023396.43 & NA & 52430256.36 \\
\hline & $\begin{array}{l}\text { Other, with at least one } \\
\text { outer ply of } \\
\text { nonconiferous wood }\end{array}$ & NA & NA & 16864601.83 & 20326671.65 & 37191273.48 \\
\hline \multirow{3}{*}{4412390000} & -- Other .... & 8820587.78 & NA & 6166818.00 & NA & 14987405.78 \\
\hline & $\begin{array}{l}\text { Other } \\
\begin{array}{l}\text { plywood, } \\
\text { consisting } \\
\text { sheets }\end{array} \\
\text { solely of }\end{array}$ & 18691987.48 & 11687164.75 & 5091579.50 & NA & 35470731.73 \\
\hline & $\begin{array}{l}\text { Other plywood, } \\
\text { consisting solely of } \\
\text { sheets of wood (other }\end{array}$ & NA & NA & 7687892.09 & 9371677.41 & 17059569.51 \\
\hline
\end{tabular}

Table 7:Imported Particle Board from 2016 - 2019

\begin{tabular}{|l|l|c|c|c|c|c|}
\hline \multirow{2}{*}{ HS CODE } & \multirow{2}{*}{ DESCRIPTION } & $\mathbf{2 0 1 6}$ & $\mathbf{2 0 1 7}$ & $\mathbf{2 0 1 8}$ & $\mathbf{2 0 1 9}$ & $\begin{array}{c}\text { GRAND } \\
\text { TOTAL }\end{array}$ \\
\cline { 3 - 7 } & & Value (N) & Value (N) & Value (N) & Value (N) & Value (N) \\
\hline \multirow{2}{*}{4410110000} & -- Particle board & 2542482.00 & 23144177.00 & 15037432.00 & NA & 40724091.00 \\
\cline { 2 - 7 } & Particle board & 17466979.40 & 11520068.49 & 11826182.92 & 12896480.90 & 53709711.70 \\
\hline
\end{tabular}

Table8: Imported Bamboo from 2016 - 2019

\begin{tabular}{|l|l|c|c|c|c|c|}
\hline HS CODE & DESCRIPTION & $\mathbf{2 0 1 6}$ & $\mathbf{2 0 1 7}$ & $\mathbf{2 0 1 8}$ & $\mathbf{2 0 1 9}$ & \multicolumn{1}{c|}{$\begin{array}{l}\text { GRAND } \\
\text { TOTAL }\end{array}$} \\
\hline 4409210000 & Of bamboo & NA & NA & NA & 22408.00 & 22408.00 \\
\hline 4412100000 & Of bamboo & 7099883.08 & 11899082.00 & 2709996.13 & NA & 21708961.21 \\
\hline & $\begin{array}{l}\text { lockboard, } \\
\text { laminboard and } \\
\text { battenboard }\end{array}$ & 3639805.90 & 12224167.08 & 4477586.64 & 2095000.00 & 22436559.63 \\
\cline { 2 - 7 } & $\begin{array}{l}\text { Other Plywood, } \\
\text { veneered panels } \\
\text { and similar } \\
\text { laminated wood } \\
\text { not specified. }\end{array}$ & NA & NA & 8599036.27 & NA & 8599036.27 \\
\hline 4418910000 & Of bamboo & NA & NA & NA & 7320311.00 & 7320311.00 \\
\hline 4419190000 & Other, of bamboo & NA & NA & NA & 6683.00 & 6683.00 \\
\hline 4421919000 & Other of bamboo & NA & NA & NA & 23798.00 & 23798.00 \\
\hline
\end{tabular}

